\title{
Power Consumption Analysis of a BLDC 24V 250W Electric Bike on An Assembled Lithium-ion Battery Pack
}

\section{Analisis Konsumsi Daya Baterai Lithium-ion Rakitan oleh Sepeda Listrik Berpenggerak Motor BLDC 24V 250W}

\author{
Wahyudi Fachrul Syafra ${ }^{1 *}$, Purwantono ${ }^{1}$, Hasanuddin ${ }^{1}$ dan Arwizet $\mathrm{K}^{1}$
}

\begin{abstract}
This research is using experimental method. Tests carried out on electric bicycles with 250 Watt Brushless DC motor drive. The total power consumption is obtained through testing the use of electric bicycles which starts from the maximum battery condition until the bike cannot move. The battery used is a type of lithium ion assembly with a total capacity of 29.12 Volt 20Ah. In testing, the bike was driven at maximum speed, with a $65 \mathrm{~kg}$ rider. In the first test, a distance of $30.6 \mathrm{Km}$ was reached with a power consumption of 1041.1 Watt, 112 minutes of travel time. The second test as far as $31.1 \mathrm{Km}$ requires 1090.8 Watts of power takes 117 minutes. And the 3rd test reached a distance of $35.9 \mathrm{Km}$ with 1178 Watts of power and 128 minutes of travel time. It was also found that the battery was unable to move the bike at the lowest voltage of 22.1 Volt.
\end{abstract}

Keywords

Lithium ion battery, power consumption, electric bike

\begin{abstract}
Abstrak
Penelitian ini menggunakan metode eksperimen. Pengujian dilakukan pada sepeda listrik dengan penggerak motor Brushless DC 24V 250 Watt. Total konsumsi daya didapat melalui pengujian pemakaian sepeda listrik yang dimulai dari kondisi baterai maksimum sampai sepeda tidak dapat bergerak. Baterai yang digunakan adalah jenis lithium ion rakitan dengan total kapasitas 29.12 Volt 20Ah. Pada pengujian, sepeda digerakan dengan kecepatan maksimalnya, dengan baban pengendara 65Kg. Pada pengujian pertama tercapai jarak 30,6 Km dengan konsumsi daya 1041.1 Watt, waktu tempuh 112 menit. Pengujian ke-2 sejauh $31.1 \mathrm{Km}$ membutuhkan daya 1090.8 Watt waktu tempuh 117 menit. Dan pengujian ke-3 mencapai jarak 35,9 Km dengan daya 1178 Watt dan waktu tempuh selama 128 menit. Didapati juga hasil bahwa baterai tidak mampu mengerakan sepeda pada tegangan terendah sebesar 22,1Volt.
\end{abstract}

\section{Kata Kunci}

Baterai lithium ion, konsumsi daya, sepeda listrik

1 Pendidikan Teknik Mesin, Universitas Negeri Padang

Fakultas Teknik, Kampus UNP Air Tawar, Jl. Prof. Dr. Hamka, Padang, Sumatera Barat. Kode Pos 25131

*wahyudifs8@gmail.com

Submitted: March 24, 2020. Accepted : May 05, 2020. Published : September 01, 2020. 


\section{PENDAHULUAN}

Pada saat ini sebagian besar masyarakat menggunakan kendaraan bermotor sebagai salah satu transportasi dalam melakukan aktivitas sehari-hari. Hal ini berdampak pada penggunaan bahan bakar yang akan meningkat dan membuat cadangan minyak bumi akan semakin menipis.

Solusi untuk menanggulanginya yaitu dengan menghadirkan kendaraan yang tidak memiliki gas buang yang berefek pada lingkungan dengan memanfaatkan energi listrik. Penelitian tentang kendaraan yang tidak memiliki gas buang yang berefek pada lingkungan dengan memanfaatkan listrik ini diantaranya adalah sepeda listrik.

Sepeda listrik memiliki beberapa keuntungan yaitu ringan sehingga dapat dipakai seperti sepeda biasa dengan menggunakan pedal, namun tenaga yang dikeluarkan oleh pengendara dapat digantikan menggunakan motor listrik. Sepeda listrik diharapkan bisa menjadi alternatif untuk mengatasi kekurangan dari sepeda biasa, sepeda yang telah dimodifikasi dengan menggunakan motor listrik dan sumber energi untuk mengerakan motor tersebut berasal dari baterai. Karena itu dibutuhkan pemilihan baterai dengan perencanaan yang matang serta memperkirakan aspek kebutuhan dimasa yang akan dating

Kelebihan baterai lithium ion adalah memiliki lifecycle panjang (500-1000 siklus), beda potensial, densitas energy, dan kapasitas spesifik lebih tinggi dibandingkan dengan baterai sekunder yang lain memberikan keuntungan dalam stabilitas kimia, dapat diisi ulang dengan cepat dan dikosongkan dengan lambat, memiliki rentan suhu operasi dan efesiensi mengisi ulang lebih 98\% serta memberikan siklus hidup lebih lama.

Baterai yang akan dirakit pada sepeda listrik ini adalah baterai Lithium Ion seperti hasil penelitian Angriccia Pangestica Saputri[1], karena memiliki kelebihan kapasitas baterai yang besar, harganya murah dan mudah didapatkan di toko elektronik, perawatan baterai lithium ion yang mudah, siklus pengisisan cukup banyak artinya bisa dipakai dan di isi berulangulang. Sumber energi listrik yang digunakan untuk mengisi ulang baterai pada umumnya berasal dari sambungan listrik rumah (PLN). Namun memiliki kekurangan bentuk lebih besar dan tebal untuk kapasitas besar, tidak kuat terhadap suhu panas tinggi. Kekurangan baterai lithium yang tidak tahan panas tinggi ini dapat diatasi saat merakit baterai dengan cara melindungi baterai dengan cover heat shrink dan baterai akan diletakan pada tempat terlindung dari terik matahari di sepeda listrik, supaya dapat menahan panas matahari.

Penelitian ini bertujuan untuk merakit baterai lithium ion sebagai sumber tenaga pengerak sepeda listrik dan menganalisis konsumsi daya baterai yang digunakan pada sepeda listrik dengan beberapa variasi kecepatan.

Kendaraan listrik merupakan salah satu langkah untuk mengurangi ketergantungan terhadap energi BBM karena jenis kendaraan ini digerakkan menggunakan motor listrik, yang di suplai menggunakan energi listrik yang disimpan dalam baterai dan tempat penyimpan energi lainnya.

Motor DC memerlukan suplai tegangan yang searah pada kumparan medan untuk diubah menjadi energi mekanik. Dalam motor dc terdapat dua kumparan yaitu kumparan medan yang berfungsi untuk menghasilkan megan magnet dan kumparan jangkar yang berfungsi sebagai tempat terbentuknya gaya gerak listrik (ggl E). Jika arus dalam kumparan jangkar berinteraksi dengan medan magnet, akan timbul torsi (T) yang akan memutar motor [2].

Pada umumnya sepeda listrik digerakkan oleh motor listrik. Konsep dari sepeda listrik sebenarnya sederhana dan relatif sama untuk setiap jenis sepeda. Baterai menyediakan arus listrik yang dibutuhkan untuk menyuplai motor listrik. Banyaknya arus dan besarnya voltase yang dibutuhkan oleh motor, diatur oleh kontroler. Dari semua sepeda listrik memiliki komponen utama yang dibutuhkan yaitu : Motor, baterai, dan kontroler[3].

Mekanisme Kerja Sepeda Listrik 
Mekanisme kerja dari sepeda listrik sanga sederhana. Mekanismenya tidak jauh beda dari sepeda biasa hanya saja ditambahkan sumber tenaga tambahan yang berasal dari baterai yang digunakan untuk menggerakkan motor sebagai tenaga gerak tambahan. Dalam mekanisme kerjanya, sepeda listrik dilengkapi oleh beberapa komponen diantaranya kontroller yang berfungsi sebagai pengatur kecepatan pada sepeda listrik[3].

\section{Baterai Lithium Ion}

Baterai merupakan elemen penting dari sebuah sepeda listrik, dan biasanya merupakan yang paling mahal. Sehingga didalam memilih baterai dibutuhkan perencanaan yang matang serta memperkirakan aspek kebutuhan di masa yang akan datang.

Baterai sebagai perangkat elektrokimia merupakan sumber kelistrikan utama bagi kendaraan. Baterai memberikan beda potensial (tegangan) melalui proses elektrokimia. Baterai tidak menyimpan energy listrik, melainkan energy kimia yang diubah menjadi energy listrik melalui proses pengosongan muatan (discharge)[4].

Salah satu jenis baterai yang banyak digunakan saat ini adalah baterai lithium ion. Ini adalah jenis baterai yang dapat di cas ulang (rechargeable).

Baterai litium ion umumnya dijumpai pada barang-barang elektronik konsumen. Baterai ini merupakan jenis baterai isi ulang yang paling populer untuk peralatan elektronik portabel, karena memiliki salah satu kepadatan energi terbaik, tanpa efek memori, dan mengalami kehilangan isi yang lambat saat tidak digunakan [5].

\section{METODE PENELITIAN}

Penelitian ini merupakan penelitian eksperimen[6] dengan melakukan analisis konsumsi daya baterai Lithium Ion 18650 rakitan pada sepeda listrik. Dalam pe;aksanaan data yang diperoleh berupa kapasitas baterai, tegangan baterai, kecepatan maksimal sepeda dan jarak tempuh sepeda dari baterai penuh sampai habis. Setelah itu dilakukan analisis terhadap data yang telah didapatkan untuk menjawab tujuan penelitian yang telah dibuat. Pelaksanaan penelitian dengan cara merakit baterai terlebih dahulu kemudian melakukan pengujian pada sepeda listrik. Gambar 1 menunjukkan Cell baterai yang akan digunakan adalah Baterai Sony G6 18650[7].
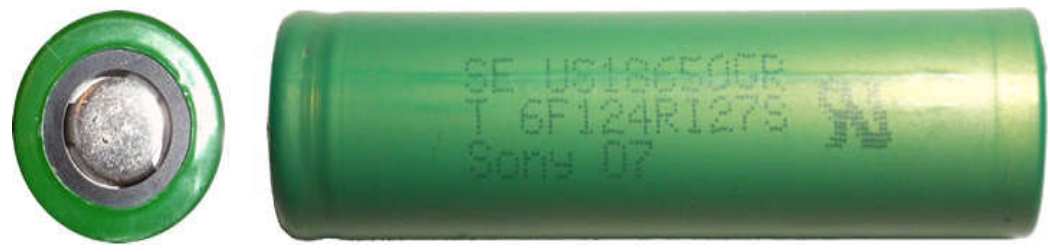

Gambar 1 Baterai sony G6 18650

\section{Perakitan baterai lithium ion}

Proses perakitan baterai lithium ion 18650 dengan kapasitas 24v 20 Ah melalui tahapan pemilihan cell baterai, menyiapkan holder/isolator cell, menyiapkan kabel sebagai penghubung arus dari setilap cell, menyiapkan susunan grub pararel dan seri nya, proses penyatuan setiap cell baterai 18650 menjadi satu kesatuan baterai sesuai skema paralel dan seri menggunakan solder, proses instalasi BMS, proses penutupan dengan isolator, pemasangan kipas dan pemasangan indikator baterai. Pada proses penyatuan cell baterai mengikuti skema paralel 7 seri, jumlah parallel yang dibutuhkan ditentukan dari hasil pengujian cell baterai.

\section{Pengujian Baterai lithium ion rakitan}


Pengujian dilakukan dengan cara mengendarai sepeda listrik dari kondisi baterai full hingga baterai tidak dapat mengerakan sepeda listrik, data yang didapatkan berupa waktu pemakaian baterai, kecepatan sepeda, temperature baterai, tegangan baterai, arus yang mengalir. Hasil data akan ditampilkan menggunakan grafik sehingga dapat diketahui maksimal pemakaian baterai lithium ion 18650. berikut:

Perhitungan daya yang dipakai dapat dilakukan dengan menggunakan rumus sebagai

$$
\begin{aligned}
& \mathrm{P}=\mathrm{IXV} \\
& \mathrm{W}=\mathrm{PXt} \\
& \mathrm{V}=\mathrm{t} / \mathrm{S}
\end{aligned}
$$

Keterangan :

$$
\begin{array}{ll}
\mathrm{P} & =\operatorname{Daya}(\mathrm{W}) \\
\mathrm{I} & =\operatorname{Arus} \text { pemakaian }(\mathrm{A}) \\
\mathrm{V} & =\operatorname{Tegangan}(\mathrm{V}) \\
\mathrm{t} & =\text { Waktu pemakaian }(\mathrm{h}) \\
\mathrm{W} & =\text { daya yang dipakai }(\mathrm{W}) \\
\mathrm{V} & =\operatorname{kecepatan} \text { sepeda }(\mathrm{Km} / \mathrm{jam}) \\
\mathrm{S} & =\text { jarak tempuh }(\mathrm{Km})
\end{array}
$$

\section{HASIL DAN PEMBAHASAN}

Gambar 2 menunjukkan bentuk fisik dari baterai yang dirakit. Pada proses penyatuan cell baterai mengikuti skema 14 paralel 7 seri, cell baterai lithium ion 18650 yang dibutuhkan sebanyak 98 cell baterai agar mendapatkan baterai sepeda listrik rakitan dengan kapasitas 29.1V 20Ah baterai akan habis pada tegangan 21V. Hal ini dapat dilihat pada tabel 2 susunan perakitan baterai. Baterai akan diuji mengunakan sepeda listrik rakitan dengan motor pengerak BLDC 24 v 250W (Gambar 3) dengan spesifikasi sepeda listrik seperti tercantum pada table 1[3]. Lokasi pengujian merupakan jalan umum yang ramai digunakan pada pagi, siang dan sore hari, untuk meminimalkan resiko kecelakaan dan pengujian yang memerlukan kondisi sepeda bergerak terus menerus maka dilakukan pada malam hari.

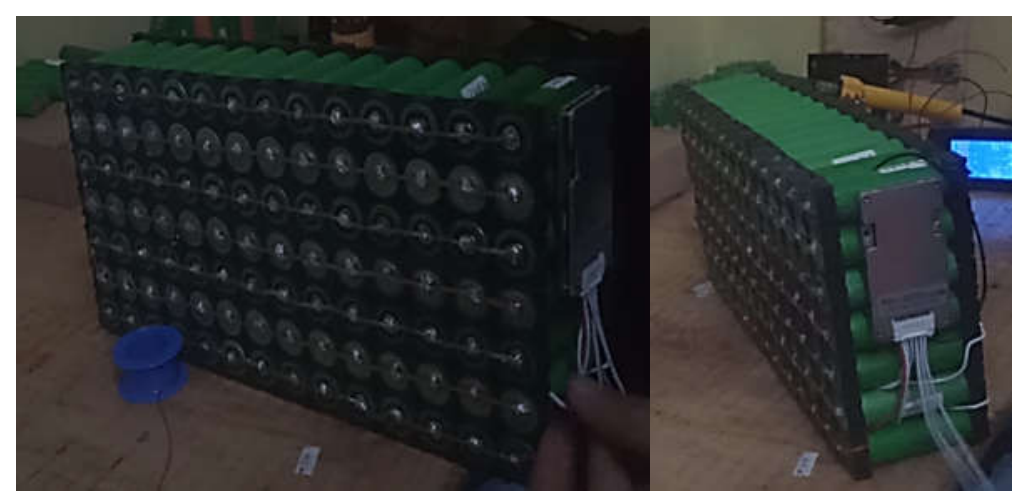

Gambar 1 Hasil rakitan baterai Lithium ion kapasitas 24V $20 \mathrm{Ah}$ 


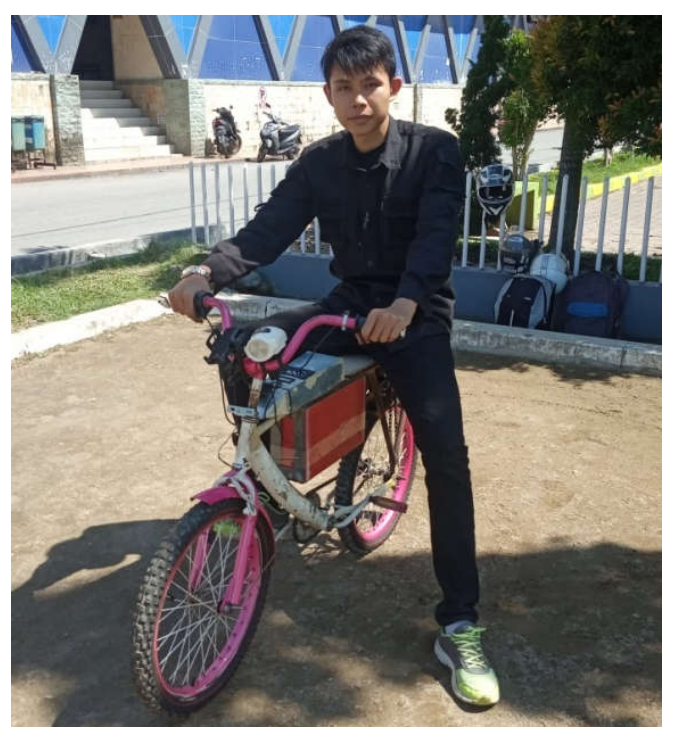

Gambar 2 Sepeda listrik rakitan mengunakan motor BLDC 24V 250W

Tabel 1 Spesifikasi kendaraan sepeda listrik

\begin{tabular}{|c|c|c|c|}
\hline No. & & Nama komponen & Ukuran \\
\hline \multirow{4}{*}{1} & \multirow{4}{*}{ Sepeda listrik } & Panjang sepeda & $143 \mathrm{Cm}$ \\
\hline & & Lebar sepeda & $63 \mathrm{Cm}$ \\
\hline & & Tinggi sepeda & $92 \mathrm{Cm}$ \\
\hline & & Berat sepeda & $14 \mathrm{Kg}$ \\
\hline \multirow{6}{*}{2} & \multirow{6}{*}{$\begin{array}{l}\text { Motor listrik BLDC } \\
\text { MY1016Z }\end{array}$} & Rated tourque & $0.80 \mathrm{Nm}$ \\
\hline & & Output speed gearbox & $330 \mathrm{RPM}$ \\
\hline & & Motor efesiensi & $78 \%$ \\
\hline & & Berat motor listrik & $2.6 \mathrm{Kg}$ \\
\hline & & Tegangan listrik motor dc & $24 \mathrm{~V}$ \\
\hline & & Daya listrik motor dc & $250 \mathrm{~W}$ \\
\hline \multirow{5}{*}{3} & \multirow{5}{*}{ Baterai } & Panjang baterai & $31 \mathrm{Cm}$ \\
\hline & & Lebar baterai & $9.5 \mathrm{Cm}$ \\
\hline & & Tinggi baterai & $19.5 \mathrm{Cm}$ \\
\hline & & Berat baterai & $6 \mathrm{Kg}$ \\
\hline & & Tegangan baterai & $24 \mathrm{~V}$ \\
\hline 4 & Berat kendaraan & Berat kendaraan & $20 \mathrm{Kg}$ \\
\hline 5 & Berat total & Berat kendaraan + pengendara $=20 \mathrm{Kg}+5 \mathrm{Kg}$ & $85 \mathrm{Kg}$ \\
\hline
\end{tabular}

Pengukuran besar nilai tegangan dan arus yang dimiliki baterai lithium ion 18650 dilakukan setelah proses perakitan. Baterai dirakit sesuai dengan Tabel 2. Berdasarkan dari data yang didapatkan maka dapat dianaliasis hasil konsumsi daya baterai 18650 lithium ion rakitan yang digunakan.

Kapasitas daya baterai : : Arus (I) 19,439

$$
\text { Tegangan (I) 29,12V }
$$

Daya (P) 566,06 Watt

Menghitung maksimal lamanya baterai memberikan arus litrik

$\mathrm{t} \quad=566,06 \mathrm{Watt} / 250 \mathrm{Watt}$

$=2,264 \mathrm{jam}$

$=135,84$ Menit

Menghitung daya maksimal yang dapat dikonsumsi

$\mathrm{W}=\mathrm{P} \times \mathrm{t}$ 
$=566,06 \times 2,264$

$=1281,559 \mathrm{Watt}$

Tabel 2 Skema rangkaian 14 paralel 7 seri

\begin{tabular}{|c|c|c|c|c|c|c|c|}
\hline \multirow{2}{*}{ No. } & \multicolumn{7}{|c|}{ Rangkaian seri } \\
\cline { 2 - 8 } & 1 & 2 & 3 & 4 & 5 & 6 & 7 \\
\hline 1 & 1,150 & 1,200 & 1,110 & 1,150 & 1,176 & 1,170 & 1,130 \\
\hline 2 & 1,211 & 1,270 & 1,155 & 1,238 & 1,157 & 1,155 & 1,160 \\
\hline 3 & 1,273 & 1,287 & 1,297 & 1,255 & 1,190 & 1,205 & 1,244 \\
\hline 4 & 1,258 & 1,150 & 1,250 & 1,146 & 1,142 & 1,126 & 1,189 \\
\hline 5 & 1,256 & 1,157 & 1,160 & 1,161 & 1,286 & 1,291 & 1,200 \\
\hline 6 & 1,250 & 1,208 & 1,208 & 1,203 & 1,201 & 1,200 & 1,200 \\
\hline 7 & 1,282 & 1,230 & 1,241 & 1,250 & 1,250 & 1,250 & 1,282 \\
\hline 8 & 1,366 & 1,326 & 1,320 & 1,290 & 1,311 & 1,311 & 1,300 \\
\hline 9 & 1,332 & 1,350 & 1,352 & 1,356 & 1,377 & 1,386 & 1,393 \\
\hline 10 & 1,450 & 1,534 & 1,500 & 1,497 & 1,442 & 1,419 & 1,410 \\
\hline 11 & 1,568 & 1,579 & 1,612 & 1,614 & 1,615 & 1,617 & 1,634 \\
\hline 12 & 1,635 & 1,715 & 1,712 & 1,711 & 1,697 & 1,689 & 1,687 \\
\hline 13 & 1,716 & 1,751 & 1,760 & 1,764 & 1,767 & 1,770 & 1,800 \\
\hline 14 & 1,857 & 1,859 & 1,810 & 1,850 & 1,850 & 1,850 & 1,847 \\
\hline $\begin{array}{c}\text { Jumlah } \\
\text { (Ah) }\end{array}$ & 19,604 & 19,616 & 19,487 & 19,485 & 19,461 & 19,439 & 19,476 \\
\hline $\begin{array}{c}\text { Tegangan } \\
\text { (V) }\end{array}$ & 4,16 & 4,16 & 4,16 & 4,16 & 4,16 & 4,16 & 4,16 \\
\hline Daya (W) & 81,552 & 81,602 & 81,065 & 81,057 & 80,957 & 80,866 & 81,020 \\
\hline
\end{tabular}

Tabel 3 hasil daya baterai setelah dirakit

\begin{tabular}{|c|c|c|}
\hline Arus (A) & Tegangan (V) & Daya (W) \\
\hline 19.439 & $29.12 \mathrm{v}$ & 566.06 \\
\hline
\end{tabular}

Tabel 4 Pengujian pada 28 Februari 2020 mulai pukul 22.02 WIB

\begin{tabular}{|c|c|c|c|c|c|c|c|c|}
\hline No. & $\begin{array}{c}\text { Waktu } \\
(\text { Menit })\end{array}$ & $\begin{array}{c}\text { Kecepatan } \\
\text { rata-rata } \\
(\text { Km/Jam })\end{array}$ & $\begin{array}{c}\text { Jarak } \\
(\mathrm{Km} \\
)\end{array}$ & $\begin{array}{c}\text { Temperatur } \\
\text { Baterai }\left({ }^{\mathrm{c}} \mathrm{c}\right)\end{array}$ & $\begin{array}{c}\text { Tegangan } \\
\text { Awal (V) }\end{array}$ & $\begin{array}{c}\text { Arus } \\
(\mathrm{I})\end{array}$ & $\begin{array}{c}\text { Daya } \\
\text { Baterai } \\
(\text { Watt })\end{array}$ & $\begin{array}{c}\text { Tegangan } \\
\text { Kerja (V) }\end{array}$ \\
\hline 1 & 8.23 & 19.24 & 2,6 & 30.9 & 28.9 & 2,64 & 76,474 & 27.2 \\
\hline 2 & 10.04 & 17,33 & 5.5 & 32.0 & 27.9 & 3,39 & 94,701 & 26.4 \\
\hline 3 & 10.20 & 17,64 & 8.5 & 31.8 & 27,8 & 3,46 & 96,23 & 26.0 \\
\hline 4 & 10.26 & 15,20 & 11.4 & 31.8 & 27.4 & 3,53 & 96,796 & 25.6 \\
\hline 5 & 1036 & 16,80 & 14.3 & 31.4 & 27.0 & 3,62 & 97,739 & 25.2 \\
\hline 6 & 10.48 & 16,60 & 17.2 & 32.5 & 26.5 & 3,73 & 98,871 & 24,9 \\
\hline 7 & 10.07 & 16,09 & 19.9 & 31.8 & 26.5 & 3,58 & 95,003 & 24.4 \\
\hline 8 & 10.13 & 15,99 & 22.6 & 32.1 & 26.3 & 3,63 & 95,569 & 24.2 \\
\hline 9 & 10.14 & 15.97 & 25,3 & 32.3 & 26.2 & 3,65 & 95,664 & 24.0 \\
\hline 10 & 10.23 & 14.07 & 27,7 & 32.6 & 25.9 & 3,72 & 96,513 & 23.8 \\
\hline 11 & 10.34 & 16,83 & 30,6 & 32.7 & 25.5 & 3,82 & 97,551 & 23.2 \\
\hline total & 112 & 16,45 & 30,6 & & & & 1041,1 & \\
\hline
\end{tabular}


Selanjutnya tabel 4 menunjukkan hasil pengujian pertama. Data pengujian konsumsi baterai sepeda listrik meliputi waktu pemakaian, kecepatan, jarak tempuh, temperature baterai dan tengangan baterai. Daya baterai didapat dari proses pengalian antara tegangan dan arus yang terukur.

Tabel 5 Pengujian pada 29 Februari 2020 mulai pukul 22.30 WIB

\begin{tabular}{|c|c|c|c|c|c|c|c|c|}
\hline No. & $\begin{array}{c}\text { Waktu } \\
(\text { Menit })\end{array}$ & $\begin{array}{c}\text { Kecepatan } \\
\text { rata-rata } \\
(\text { Km/jam) }\end{array}$ & $\begin{array}{c}\text { Jarak } \\
(\text { Km })\end{array}$ & $\begin{array}{c}\text { Temperatur } \\
\text { Baterai }\left({ }^{\circ} \mathrm{C}\right)\end{array}$ & $\begin{array}{c}\text { Tegangan } \\
\text { Awal (V) }\end{array}$ & $\begin{array}{c}\text { Arus } \\
(\mathrm{I})\end{array}$ & $\begin{array}{c}\text { Daya } \\
\text { Baterai } \\
\text { (Watt) }\end{array}$ & $\begin{array}{c}\text { Tegangan } \\
\text { Kerja (V) }\end{array}$ \\
\hline 1 & 10.02 & 17,96 & 3.0 & 31.1 & 28.9 & 3,21 & 92,862 & 26.6 \\
\hline 2 & 10.01 & 18,58 & 6.1 & 31.1 & 28.2 & 3,28 & 92,769 & 26.4 \\
\hline 3 & 10.07 & 16,08 & 8.8 & 31.2 & 27.8 & 3,35 & 93,325 & 26.0 \\
\hline 4 & 10.01 & 16,78 & 11.6 & 31.7 & 27.4 & 3,38 & 92,769 & 25.8 \\
\hline 5 & 10.23 & 16.42 & 14.4 & 31.3 & 27.1 & 3,49 & 94,808 & 25.6 \\
\hline 6 & 12.56 & 18,15 & 18.2 & 32.3 & 27.0 & 4,31 & 116,401 & 25.0 \\
\hline 7 & 10.23 & 14,66 & 20.7 & 31.7 & 26.6 & 3,56 & 94,808 & 25.2 \\
\hline 8 & 10.13 & 17,17 & 23.6 & 32,6 & 26.4 & 3,55 & 93,881 & 24.5 \\
\hline 9 & 10.02 & 16.80 & 26.4 & 31.3 & 26.1 & 3,55 & 92,862 & 24.0 \\
\hline 10 & 10.01 & 14,40 & 28.8 & 32.0 & 25.8 & 3,59 & 92,769 & 23.8 \\
\hline 11 & 10.21 & 11,16 & 30.7 & 33.1 & 25.6 & 3,69 & 94,622 & 22.5 \\
\hline 12 & 4.20 & 5,71 & 31.1 & 33.3 & 25.2 & 1,54 & 38,924 & 22.1 \\
\hline Total & 117,7 & 15,323 & 31,1 & \multicolumn{7}{r|}{} \\
\hline
\end{tabular}

Tabel 6 Pengujian pada 03 Maret 2020 mulai pukul 22. 23 WIB

\begin{tabular}{|c|c|c|c|c|c|c|c|c|}
\hline No. & $\begin{array}{c}\text { Waktu } \\
(\text { Menit })\end{array}$ & $\begin{array}{c}\text { Kecepatan } \\
\text { rata-rata } \\
(\text { Km/jam) }\end{array}$ & $\begin{array}{c}\text { Jarak } \\
(\mathrm{Km})\end{array}$ & $\begin{array}{c}\text { Temperatur } \\
\left.\text { Luar( }{ }^{0} \mathrm{C}\right)\end{array}$ & $\begin{array}{c}\text { Tegangan } \\
\text { Awal (V) }\end{array}$ & $\begin{array}{c}\text { Arus } \\
(\mathrm{I})\end{array}$ & $\begin{array}{c}\text { Daya } \\
\text { Baterai } \\
\text { (Watt) }\end{array}$ & $\begin{array}{c}\text { Tegangan } \\
\text { Kerja (V) }\end{array}$ \\
\hline 1 & 10.05 & 18,50 & 3.1 & 28 & 29.0 & 3,26 & 94,815 & 27.1 \\
\hline 2 & 10.32 & 18.02 & 6.2 & 28 & 28.4 & 3,42 & 97,362 & 26.2 \\
\hline 3 & 10.16 & 17,71 & 9.2 & 28 & 27.3 & 3,51 & 95,852 & 26.0 \\
\hline 4 & 10.06 & 17,89 & 12.2 & 28 & 27.0 & 3,51 & 94,909 & 25.3 \\
\hline 5 & 10.13 & 17,76 & 15.2 & 28 & 26.7 & 3,57 & 95,569 & 25.3 \\
\hline 6 & 9.40 & 17.87 & 18.0 & 26 & 27.0 & 3,28 & 88,682 & 25.0 \\
\hline 7 & 9.40 & 17.23 & 20.7 & 26 & 26.6 & 3,33 & 88,682 & 24.6 \\
\hline 8 & 9.40 & 17.84 & 23.5 & 26 & 26.4 & 3,35 & 88,682 & 24.4. \\
\hline 9 & 9.40 & 17.23 & 26.2 & 26 & 26.2 & 3,38 & 88,682 & 24.3 \\
\hline 10 & 9.41 & 17.21 & 28.9 & 26 & 25.9 & 3,42 & 88,777 & 24.1 \\
\hline 11 & 10.47 & 17.19 & 31.9 & 26 & 25.7 & 3,84 & 98,777 & 23.4 \\
\hline 12 & 9.43 & 13.99 & 34.1 & 26 & 25.3 & 3,51 & 88,965 & 22.8 \\
\hline 13 & 7.28 & 14,83 & 35.9 & 26 & 25.1 & 2,73 & 68,681 & 22.4 \\
\hline Total & 128 & 16,85 & 35,9 & \multicolumn{7}{|l}{} & & 1178,4 & \\
\hline
\end{tabular}

Pengujian pertama waktu pemakaian 112 menit mencapai jarak tempuh 30,6 Km dengan pemakain daya baterai 1041,1 Watt. Pada saat pengujian waktu tempuh 112 menit baterai berhenti memberikan arus pada tegangan kerja $23,2 \mathrm{~V}$. Saat pengujian hendle sepeda di putar 
pada posisi penuh sehingga menghasilkan kecepatan penuh, akibatnya motor memerlukan tegangan yang lebih tinggi agar dapat mengerakan sepeda listrik. Penelitian dihentikan pada no 11 karena baterai beberapa saat berhenti memberikan arus untuk mengerakan sepeda listrik.

Tabel 5 menunjukkan hasil pengujian kedua, waktu pemakaian 117 menit mencapai jarak tempuh 31,1 Km daya yang dipakai 1090,08 Watt. Jarak tempuh di pengujian 2 lebih jauh karena pada menit 110-117 sepeda listrik tidak dipaksa untuk bergerak pada putaran hendle penuh, sehingga kecepatan hanya mampu bertahan di 5,71 Km/jam, sampai pada tegangan 22,1V baterai berhenti memberikan arus untuk mengerakan sepeda listrik.

Tabel 6 menunjukkan hasil pengujian ketiga, waktu pemakaian 128 menit mencapai jarak tempuh $35,9 \mathrm{Km}$ daya yang dipakai 1178,4 Watt. Pada pengujian ini sepeda listrik dari menit 110-128 sepeda bergerak dengan kecepatan rendah sehingga hanya memerlukan tegangan yang rendah akibatnya jarak tempuh menjadi lebih jauh dari pada pengujian sebelumnya. Pada nomor 13 baterai beberapa saat sudah berhenti memberikan arus, jika handle sepeda dipaksa diputar penuh tegangan baterai menjadi turun sangat cepat akibatnya baterai berhenti memberikan arus listrik.

Tabel 7 Waktu pengisian baterai

\begin{tabular}{|l|l|l|l|l|l|}
\hline No. & Tanggal & Pengisian awal & Pengisian akhir & Waktu Pengisian & Tegangan Akhir \\
\hline 1. & 29 Februari 2020 & 01.57 & 09.46 WIB & 7 Jam 49 Menit & $29.1 \mathrm{~V}$ \\
\hline 2. & 01 maret 2020 & 3.23 & 11.14 WIB & 7 jam 51 menit & $29.1 \mathrm{~V}$ \\
\hline 3. & 04 maret 2020 & 15.12 & 23.25 WIB & 8 jam 13 menit & $29.1 \mathrm{~V}$ \\
\hline
\end{tabular}

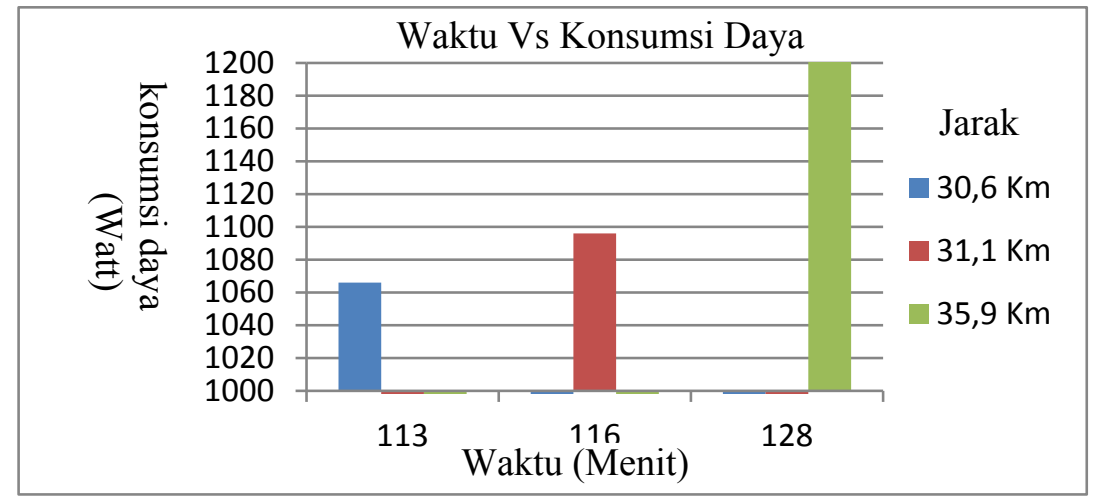

Gambar 4 Grafik perbandingan jarak, waktu dan konsumsi daya

Berdasarkan data yang didapatkan pada ketiga pengujian sepeda digerakan dengan kecepatan maksimalnya, pengujian dilakukan dengan baban pengendara $65 \mathrm{Kg}$, tegangan baterai terus mengalami penurunan seiring bertambahnya jarak tempuh, jarak tempuh pada pengujian pertama $30,6 \mathrm{Km}$ dan ke-2 sejauh $31.1 \mathrm{Km}$, jarak tempuh terbesar terjadi pada pengujian ke-3 yaitu $35,9 \mathrm{Km}$. Apabila dibandingkan dengan kondisi waktu yang sama pada nomor 11 maka jarak tempuh ketiga pengujian tidak jauh berbeda yaitu 30,6Km, 30,7KM $31,9 \mathrm{Km}$. Dari ketiga pengujian sampai di nomor 11 sepeda dapat bergerak dengan putaran hendle penuh namun pada waktu selajutnya harus dikurangi karena pada menit tersebut baterai sudah sesekali berhenti memberikan arus untuk mengerakan sepeda hal ini disebabkan tegangan baterai yang terus turun. Pada nomor 12-13 sepeda hanya mampu bergerak dengan kecepatan rendah. Apabila sepeda dipaksa bergerak pada kecepatan tertinggi baterai tidak mampu mengerakan sepeda hal ini disebabkan tegangan baterai akan cepat turun dan berhenti memberikan arus listrik.

Hal ini menunjukan adanya pengaruh kondisi kecepatan terhadap konsumsi baterai, dimana pada kecepatan tinggi membutuhkan tegangan baterai yang lebih besar dari pada 
kecepatan yang lebih rendah, semakin tinggi kecepatan maka tegangan baterai akan turun lebih besar untuk mengerakan sepeda listrik, Tegangan awal baterai 29.0V tegangan paling rendah pada $22.1 \mathrm{~V}$ dibawah itu baterai tidak dapat mengerakan sepeda listrik, baterai akan habis pada tegangan $21 \mathrm{~V}$.

Pada grafik perbandingan jarak konsumsi daya dengan waktu dapat dianalisis semakin tinggi kecepatan maka waktu tempuh akan lebih cepat namun membutuhkan konsumsi baterai yang lebih besar, pada kondisi kecepatan lebih rendah waktu tempuh semakin lama tetapi konsumsi daya yang dibutuhkan lebih sedikit.

Kondisi temperature baterai saat pengujian terendah $30,6{ }^{\circ} \mathrm{C}$ maksimal temperature baterai $33,3{ }^{\circ} \mathrm{C}$, dari ketiga pengujian menunjukan temperature baterai akan meningkat seiring dengan lamanya waktu pakai baterai, namun kondisi ini masih diantara Temp. discharge, min-max baterai Lithium ion 18650 SONY G6, $-20.00^{\circ} \mathrm{C}-60.00^{\circ} \mathrm{C}$. Apabila baterai mengalami temperature melebihi hal ini pengunaan baterai harus dihentikan agar menjaga kondisi baterai selalu dalam keadaan baik. Lama pengecasan baterai paling rendah 7 jam 49 menit dan paling lama 8 jam 13 menit, baterai akan semakin lama membutuhkan pengecasan apabila baterai digunakan lebih lama.

\section{SIMPULAN DAN SARAN}

\section{Simpulan}

Proses penyatuan cell baterai mengikuti skema 14 paralel 7 seri, cell baterai ithium ion 18650 yang dibutuhkan sebanyak 98 cell baterai agar mendapatkan baterai sepeda listrik rakitan dengan kapasitas penuh 29.1V 20Ah dengan daya 566.06W baterai akan habis pada tegangan $21 \mathrm{~V}$.

Pada pengujian sepeda digerakan dengan kecepatan maksimalnya, pengujian dilakukan dengan baban pengendara $65 \mathrm{Kg}$, tegangan baterai terus mengalami penurunan seiring bertambahnya jarak tempuh, jarak tempuh pada pengujian pertama 30,6 Km membutuhkan daya 1041,1W dan ke-2 sejauh $31.1 \mathrm{Km}$ membutuhkan daya 1090,8W, jarak tempuh terbesar terjadi pada pengujian ke-3 yaitu 35,9 Km membutuhkan daya 1178,4 W. Pada nomor 1-11 kecepatan terus berkurang seiring dengan berkurangnya tegangan baterai, pada menit 12-13 sepeda hanya mampu bergerak dengan kecepatan rendah. Apabila sepeda dipaksa bergerak pada kecepatan tertinggi baterai tidak mampu mengerakan sepeda dan berhenti memberikan arus listrik. Hal ini menunjukan adanya pengaruh kondisi kecepatan terhadap konsumsi baterai, dimana pada kecepatan tinggi membutuhkan tegangan baterai yang lebih besar dari pada kecepatan yang lebih rendah, semakin tinggi kecepatan maka tegangan baterai akan turun lebih besar untuk mengerakan sepeda listrik. Lama pengecasan baterai paling rendah 7 jam 49 menit dan paling lama 8 jam 13 menit, baterai akan semakin lama membutuhkan pengecasan apabila baterai digunakan lebih lama.

\section{Saran}

Pemilihan baterai harus berdasarkan beberapa faktor diantaranya biaya, spesifikasi baterai, serta komponen yang ada dipasaran. Daya baterai yang dirakit harus mempertimbangkan jumlah daya yang dibutuhkan motor listrik yang dipakai supaya baterai mampu mengerakan sepeda lisrik, Perakitan baterai sepeda apabila baterai kondisi bekas harus dilakukan pengujian terlebih dahulu agar kapasitas dari setiap cell dapat diketahui, supaya dapat memudahkan dalam penyusunan skema paralel dan serinya. Pemakaian sepeda listrik apabila tegangan baterai dalam kondisi rendah dari $25,2 \mathrm{~V}$ sebaiknya sepeda dikendarai dengan kecepatan rendah dan dapat dibantu dengan gerakan pedal. Supaya tegangan baterai tidak turun dengan cepat yang membuat baterai berhenti memberikan arus untuk mengerakan sepeda listrik. 


\section{DAFTAR RUJUKAN}

[1] A. P. Saputry, T. Lestariningsih, and Y. Astuti, "The Effect of Ratio LiBOB: TiO2 of Electrolyte Polymer Sheets as separators on the Electrochemical Performance of LTOBased Lithium-Ion Batteries," J. Kim. Sains Dan Apl., vol. 22, no. 4, pp. 136-142.

[2] S. Agustina and N. Nugroho, "Analisa Motor Dc (Direct Current) Sebagai Penggerak Mobil Listrik," J. Mikrotiga, vol. 2, no. 1, 2015.

[3] S. Pareza, P. Purwantono, R. Lapisa, and P. Primawati, "Build Design Of Electric Bike As Energy Efficient Transportation,” Motiv. J. Mech. Electr. Ind. Eng., vol. 2, no. 2, pp. 65-72, May 2020.

[4] P. Philip, Sistem kelistrikan otomotif. Jogjakarta: Graha Ilmu.

[5] M. T. Afif and I. A. P. Pratiwi, "Analisis Perbandingan Baterai Lithium-Ion, LithiumPolymer, Lead Acid dan Nickel-Metal Hydride pada Penggunaan Mobil Listrik - Review," Rekayasa Mesin, vol. 6, no. 2, pp. 95-99, Aug. 2015, doi: 10.21776/ub.jrm.2015.006.02.1.

[6] A. Jaedun, “METODOLOGI PENELITIAN EKSPERIMEN," p. 13.

[7] "Sony G6 18650 Battery, 2200mAh, 2.2A, 3.6V, Grade A Lithium-ion (US18650G6G)," Voltaplex Lithium Ion Battery Packs. https://voltaplex.com/sony-g6-18650-batteryus18650g6g (accessed May 04, 2020). 